\title{
PIONEER
}

VOLUME 12, Issue 1, June 2020: 73 - 87

\section{AN ANALYSIS OF CODE MIXING IN BAYU SKAK'S VIDEOS}

\author{
Raudatul Hasanah \\ Universitas Abdurachman Saleh Situbondo \\ raudatulhasanah16@gmail.com
}

\begin{abstract}
This study investigated the types and factors that influence code mixing in Bayu Skak's videos. The data in this study are in the form of utterances that contain code mixing in Bayu Skak's videos. This research was conducted by analyzing the data qualitatively. The research instruments are the researcher herself. There were three videos that was used in this research. The techniques of data collection were done by watching Bayu Skak's videos one by one, noting down the utterances that contained code mixing, and giving numbers and codes in every utterance that contained code mixing and analysing the data based on Spradley's theory (1965). The steps of data analysis are domain analysis, taxonomy analysis, componential analysis, and cultural values. The finding of the research described types and factors that influence the code mixing and the total data showed thirty two data used code mixing from types of code mixing which attained eleven data from insertion, eight data of alternation, and eleven data of congruent lexicalization. Then, factors that influence code mixing cover four need for synonymy, four data of social value, three data of intrduction and development of new culture, five data of low frequency or word, five data of oversight, five data of pernicious homonymy, four data of in sufficiently differentiated, and two data of end.
\end{abstract}

Keywords: Bayu Skak, code mixing, Youtube videos

\section{INTRODUCTION}

Languages used in society can be different. There are some ways of interaction done to deliver a message. One example of means of communication is video. A video is a program, movie, or other visual media product featuring moving images, with or without audio, that is recorded and that is recorded and saved digitally or on videocassette (Dictionary.com, 2018). A video can demonstrate communicative language within a language environment and cultural context (Wood, cited in Aiex, 1999). Through the use of videos, people can learn some new vocabularies from other languages. This is influential to change mindset and way of communication. In daily communication, people usually choose different codes in different situation. A code is a system used for communication between two or more parties used on any occasion (Wardhaugh, 2006, p. 101). When people want to talk each other, they have to choose a 
particular code express their feeling. Besides, a code occurs not only in conversation, novel, newspaper, etc, but also in short video, such as Bayu Skak's videos.

In this area, many people use vlogs to upload their videos on Youtube. The videos show unique themes and make people interest to watch. From these videos, people can study everything like cooking, make up, music, English, games, and everything else. People choose the videos based on their interest. This kind of videos is called vlogs (video blogs) that are broadcasted in a channel. Vlogs are famous in teenager. There are many channels or videos with several languages and show unique themes or Youtube. However, the researcher chose Bayu Skak's videos or channel because he is the first person who used Javanese accent mixed with Indonesian and English to be recorded as a Youtube content. Bayu Skak's videos discuss unique themes such as teenagers' life, the habit of cursing in East Java, and the commentator games. These videos use Javanese mixed with Indonesian, and English. This research focuses on code mixing found and used in Bayu Skak's videos.

The topic of code mixing was chosen because the researcher wanted to observe about what code mixing found in the Bayu Skak's videos. The researcher also wanted to analyze the types and factors that influenced the use of code mixing used Bayu Skak's Videos. So, the researcher formulated the research questions as the followings: What are code mixings found in Bayu Skak's Videos? What are the types of code mixings in Bayu Skak's Videos? and What factors that influence Bayu Skak to use code mixing in his videos? One of the purposes of this study was giving knowledge about code mixing used by society in communication with indigenous or foreigner in daily life. The result of this research was also expected to give benefits for the next researchers as a reference.

\section{REVIEW OF LITERATURE}

\section{Sociolinguistics}

Sociolinguistics is a study of our everyday lives-how language works in our live casual conversations and the media we are exposed to and the presence to societal norm, policies, and law which address language. Wardhaugh (2006) also explains that Sociolinguistics is concerned with investigating the relationships between language and society with the goal of a better understanding of the structure of language and how language function in communication. Sociolinguistics studies about society and 
language, and it aims to investigate about what of thing language is used in the society based on its social functions (p. 13).

\section{Context of Situation}

Halliday in Adenan (2000) states that the context in which language is used is a major influences on the types of language used (p. 270). In the SFL model of language, context of situation is examined from three aspects: field, tenor and mode. Field refers to what is happening, to the nature of social action that is taking place. Tenor refers to who is taking part, to the nature of the participants, their status and roles: what kind of role relationships obtain among participants, including permanent and temporary relationships of one kind or another, both the types of speech role that they are taking on in the dialogue and the cluster of socially significant relationships in which they are involved. Mode refers to what part the language is playing, what it is that the participants are expecting the language to do for them in that situation (Halliday in Shiqun $\mathrm{Hu}, 2010$, p. 324).

\section{Code Mixing}

Code mixing generally refers to alternations between varieties or codes, within a clause or phrase. Wardaugh (2006) states that code mixing is the use of two languages together by conversant the extent that they change from one language to the other in the course of a single utterance. Code mixing occurs when the speakers use a language in a dominant of a speech inserted elements of other languages (p. 103). The process code mixing is caused by the characteristic of speakers like social and education level. The characteristic of code mixing often shows form of situation informal.

\section{Types of Code Mixing}

According to Muysken (2000), there are three basic processes that are constrained by different structural conditions, and are operant to a different extent and in different ways in specific bilingual settings (p. 03), they are:

\section{Insertion}

Insertion views the constraints in terms of the structural properties of some base or matrix structure. Here the process of code-mixing is conceived as something akin to borrowing: the insertion of an alien lexical of phrasal category into a given structure 
(Muysken, 2000, p. 03). This means insertion of such as lexical item or entire constituents from one language into a structure from the other language.

Example: Tapi, tak pada screenshot. (noun)

Dengan kata lain bikin kalian respon. Ya, True story, Bro! (noun phrase)

2. Alternation

Muysken (2000) stated that it is constraints on mixing in terms of the compatibility or equivalence of the language involved at the switch point (p. 04). Alternation occurs when structure of two languages are alternated indistinctively both at the grammatical and lexical level between structure and from languages.

Example: The more you know, vlog pertama yang aku upload 2010, komennya Masya Allah wes.

3. Congruent lexicalization

The term congruent lexicalization refers to a situation where the two languages share a grammatical structure which can be filled lexically with element from either language (Muysken, 2000, p. 06). The kind of code mixing occurs at phonological level, as when Indonesian says an English word, but modify it into Indonesian phonological structure. Example: $99 \%$ dari handphone adalah hal yang bakal menyita waktu kalian yang akan sia-sia: SMS, BBM, Line, Twitter, Instragram, selfi,..

\section{Factors that Influence Code Mixing}

There are factors that influence code mixing. Weinreich (1963) in Hasanah (2017, p. 16) states that these factors can be distinguished into two types, they are attitudinal types and linguistic type.

\section{Attitudinal type}

Attitudinal type is code mixing that depends on one's attitude (seen from the speaker's attitude background). There are factors of attitudinal type consist of:

a) Need for synonym

A speaker uses word from another language which has the same meaning or synonymous to soften the aim of the utterance.

Example: Nah, setelah shooting baru kita edit.

b) Social value

A speaker takes the word from another language by considering social factors. The use of the word shows the social status of the speaker. 
Example: Hei, rek! Hei, guys!

c) Introduction and development of new culture

Development of new culture is one of the factor influencing code mixing because there are many terminologies in every field like fashion, marketing, business that use foreign languages. In this case, society mixes foreign languages with their language their daily in communication.

Example: Nah, dan youtube network ini banyak sekali seperti contohnya ini (freedom) ini (layaria), ini (broadbrandful) ini (master), ini (markegen), ini (fullscreen).

\section{Linguistic type}

According to Weinreich in Hasanah (2017) linguistic type can be seen from background, the factors causing are divided into five types (p. 16):

a) Low frequency or word

It means that the word in another language is easier to remember and sense of the word is more stable. A speaker uses a usual word from other language with the aim listener or respondent understand the meaning what speaker said.

Example: Hari ini aku akan bahas tentang handphone.

b) Pernicious homonymy

A speaker uses a word from another language to solve homonymy problem in his/her language. If the speaker uses a word from his/her own language, the word makes homonymy problem namely ambiguous meaning. Therefore, the speaker borrow the word from another language to evade ambiguous meaning.

Example: Dan setiap bulannya bayangkan total viewnya 100 juta view.

c) Oversight

This factors related to limitation word the speaker's language. It means when the speaker conveys a topic but he has the limitation of the word so the speaker will mix or take the word from other language, Weinreich in Muysken (2001) states that thought that intra-sentential code mixing was a sign of lack bilingual proficiency and interference (p. 01).

Example: Apakah saja keuntungan dari Youtube?

d) In sufficiently differentiated

It shows meaning of certain have specific intent, for instance habit.

Example: Oh my god, ini memang tidak bisa dibiarkan, teman-teman! 
e) End

The factors mean purpose and goal which the result or the consequence that is wanted like as persuasive, persuade, and explanation.

Example: Ayolah kalian tau sendiri kan konsekuensinya bakalan bagaimana? Oh my God. Don't do it...don't do it.

\section{Bayu Skak's Videos}

Bayu Skak made comedy videos which discuss about teenagers life, the habit of cursing in East Java, and commentator of games. He began to make videos with his friends when he was a student at Junior high school. Then, Bayu and his friends made a comedian group called as SKAK or Sekumpulan Arek Kesel. After that, they made simple videos like lip-sync video and uploaded their video in the their channel of Youtube. Their videos went viral in their classmate or schoolmate. Then many people started to know their videos. In 2011, they were vacuum, because the member of SKAK graduated from junior high school, but in 2012, Bayu began to make videos again using name "SKAK". He uses accent of Javanese and mixes Indonesian, Javanese and English. Bayu Skak's channel got more than 1.000.000 (one million) subscribers. Now, Bayu Skak has three channels consist of Vlog Bayu Skak, Bayu Skak Daily life, and Bayu Skak WTB (with the band).

\section{METHOD}

This research used qualitative method. The data of this research are utterances that contain code mixing in Bayu Skak's videos. Whereas, the source of data is Bayu Skak's videos. Researcher took three videos to be used as the data, they are Di balik layar SKAK (Behind the scene of SKAK, April 25, 2015), and Terserah (Up To You, April 18 2015). This instrument was used for collecting the data. The instrument was the researcher herself. In collecting the data, the researcher took some steps, namely: watching Bayu Skak's videos one by one, noting down the utterances that contained code mixing, and giving numbers and codes in every utterance that contained code mixing.

This research used Spradley's theory to analyze the data which can be done through four steps, they are: domain analysis, taxonomy analysis, componential analysis, and cultural values. In domain analysis, the researcher chose sentences that contained code mixing. Then researcher noted down Bayu's utterances that contained 
code mixing. In domain analysis, the researcher chose sentences that contained code mixing. Then researcher noted down Bayu's utterances that contained code mixing. In taxonomy analysis, the researcher classified the data based on certain categories. According to Spradley (1956), component analysis is the systematic search for the attributes (components of meaning) associated with cultural categories (p. 131). In componential analysis, the researcher related the utterances containing code mixing found with the classification based on types of code mixing and factors influencing code mixing. Then, the researcher counted the total data found in every video.

Cultural values is conclusion from all of the information of this research begin of code mixing found, types of code mixing, factors that influence the use of code mixing then relate to data taken in the video. Then, the researcher analyzed them and compared them to the theories.

\section{FINDINGS AND DISCUSSION}

\section{Findings}

The researcher found thirty two data of code mixing in Bayu Skak's videos which consist of types and factors that influence code mixing. The first, types of code mixing which attained are ten data of insertion, ten data of alternation, and twelve data of congruent lexicalization. Then, the researcher found factors that influence of code mixing has eight patterns namely four data of need for synonymy, four data of social value, three data of intrduction and development of new culture, five data of low frequency or word, five data of oversight, five data of pernicious homonymy, four data of in sufficiently differentiated, and two data of end.

The findings were obtained based on Weinreich's theory (1963) about factors that influence code mixing and Muysken's theory for types of code mixing in Bayu Skak's videos.

\section{Insertion}

Insertion is lexical item or entire constituents from one language into a structure from the other language. It may consist of noun and phrase. There are many data from Bayu Skak's videos, they are:

Datum 001/BSV1/00:00:00

Bayu : Hello, Friends! Berjumpa lagi dengan saya Bayu skak.

(Hello, Friends! meet again with me Bayu Skak!) 
Context of situation:

Bayu Skak greeted his viewers to begin his program. The setting (S) happened in the meeting room. Participants are viewers and instruments (I), spoken was recorded by using camera and published on Youtube. End is greeting. Key used in this utterance is loud voice and calmly.

The utterance "Hello, Friends! Berjumpa lagi dengan saya Bayu skak" was used by Bayu Skak when he greeted his viewer in Indonesia or abroad. In the using of utterances he applied code mixing to insertion which entire constituents from one language into a structure from the other language because "Hello, Friends" is a single word form noun. In this utterance, Bayu mixed Indonesian and English because he knew his viewers are not only from Indonesia.

Attitudinal type of Social value is the factors that influences code mixing Bayu took a word from another language by social factors. The factors influencing the code mixing used is attritional type. This is because the speaker began his program calmly in loud voice and control stage over so he attracted the viewers' attention.

\section{Alternation}

It is two languages show into clause but still relatively apart. In this case, the structure almost similar with insertion. However, when a series of the diverted begins and in follow by the elements of other and elements were not connect structurally then it can also called alternation.

Datum 003/BSV1/00:02:10

Bayu : Nah. jadi, begitu! get it? Got it? Good!

(Nah. So, that is it! Get it? Got it? Good!)

Context of situation:

Bayu answered and ask to viewers what viewers understand about explanation from Bayu Skak. The setting (S) happened in the meeting room. Participants are viewers and Instruments (I), Spoken was recorded by using camera and published to Youtube. End is asking. Key used in this utterance is informal. Then asking to viewers about topic as acts sequence.

Bayu explained the meaning of SKAK and behind of scene in the Skak to viewers, when he finished explaining, then he gives conclusion with asking to viewers like as "Nah. Jadi, begitu! get it? Got it? Good!" Bayu mixed Indonesian and English. 
He used the mixing of language to evade ambiguous meaning. In this case, Bayu's utterances applied code mixing to alternation occurs structure of two languages are alternated indistinctively both at grammatical and lexical level between structure and from languages.

The factor that influenced the code mixing is linguistic type, that is pernicious homonymy. It is meaning to solve homonymy problem in his or her languages. The factor influencing the code mixing used is linguistic type. This is because Bayu's diction is clearly and varied which can be understood by viewers.

\section{Congruent lexicalization}

Congruent lexicalization mixes lexical material from different usage occurs in a shared grammatical structure. In this process, there are linear and structural equivalence on syntax among variety of language and also associated with variety of dialect or standard.

Datum 004/BSV1/00:05:36

Bayu : Pertama-tama kawan-kawan kita bikin dulu scriptnya.

(First, we made the script).

Context of situation:

Bayu informed to viewers about the way of making video. The setting (S) happened in the meeting room. Participants are viewers and Instrumentalities (I), Spoken was recorded by using camera and published to Youtube. End is giving information. Key is serious. Then, talking about to make video as acts sequence.

Bayu informed that the making of video to first step was making script. Bayu mixed Indonesian and English languages. He used the mixing of language to considering social factors. In the case, Bayu's utterances applied code mixing to congruent lexicalization refers to a situation where the two languages share a grammatical structure which can be filled lexically with element from either language.

The factor that influenced the code mixing is linguistic type, that is social value means by considering social factors. The use of the word shows the social status of the speaker. The factor influencing the code mixing used is attitudinal type. This is because Bayu choice of word clearly and varied which can be understood by viewers. 


\section{Cultural Values}

Code mixing is the use of two languages together by conversant the extent that they change from one language to the other in the course of a single utterance (Wardhaugh, 2006, p. 103). Code mixing occurs when speaker mixed Indonesian, Javanese and English. In daily communication, people often use code mixing and some program especially in for example entertainment, program or channel videos in Youtube.

In this research, the researcher found three types of code mixing consist of insertion, alternation, and congruent lexicalization. The researcher also found also eight factors that influence the code mixing, namely need for synonymy, social value, introduction and development of new culture, low frequency or word, pernicious homonymy, oversight, in sufficiently difference, and end. The types of code mixing used Muysken's theory and factors that influence of code mixing used Weinreich's theory.

Table Componential Analysis

\begin{tabular}{|c|c|c|c|c|c|c|c|c|}
\hline \multirow[b]{2}{*}{$\begin{array}{l}\text { Types of } \\
\text { code } \\
\text { mixing }\end{array}$} & \multicolumn{8}{|c|}{ Factor the influence of code mixing } \\
\hline & $\begin{array}{l}\text { Need for } \\
\text { Synonym }\end{array}$ & $\begin{array}{l}\text { Social } \\
\text { Value }\end{array}$ & $\begin{array}{c}\text { Introduction } \\
\text { and } \\
\text { Development } \\
\text { of New } \\
\text { Culture }\end{array}$ & $\begin{array}{c}\text { Low } \\
\text { Frequency } \\
\text { or word }\end{array}$ & $\begin{array}{l}\text { Pernicious } \\
\text { Homonyny }\end{array}$ & $\begin{array}{l}\text { Over- } \\
\text { sight }\end{array}$ & $\begin{array}{c}\text { In } \\
\text { Sufficien } \\
\text { tly } \\
\text { differenti } \\
\text { ated } \\
\end{array}$ & $\begin{array}{c}\text { En } \\
\text { d }\end{array}$ \\
\hline Insertion & 3 & 2 & - & 3 & - & 1 & 1 & - \\
\hline Alternation & 1 & - & - & 1 & 1 & 1 & 3 & 3 \\
\hline $\begin{array}{l}\text { Congruent } \\
\text { Lexicalliza } \\
\text { tion }\end{array}$ & - & 1 & 3 & 2 & 3 & 3 & - & - \\
\hline
\end{tabular}

The result of table above showed that there were factors influenced of code mixing. Factors that influence they are of insertion were need for synonym, social value, low frequency or word, oversight and in sufficiently differentiated. Then, the second type was alternation influenced by factor of need for synonym, low frequency or word, pernicious homonymy, oversight, in sufficiently differentiated and end. The last type were influenced by factors of social value, introduction and development of new culture, low frequency or word, pernicious homonymy, and oversight. 


\section{Discussion}

In this study, the researcher used Bayu Skak's videos as the data source. The researcher found many code mixings in the video. Then, researcher analyzed the types of code mixing used Muysken's theory and factors that influence the code mixing used Weinreich's theory. This study focusses to find code mixing in Bayu Skak's Video and analyze on types and factors that influence code mixing. The data source is Bayu Skak's videos on Youtube.

In finding the results, the researcher described the data based on the types and factors that influence the code mixing. However, types of code mixing were influenced by factors caused speaker or Bayu mix Javanese, Indonesian and English because the aim of speaker where every speaker told based on the context and situation. Then, the second analysis factors that influence the code mixing based on context of situation found two type consist of attitudinal type and linguistic type. In the Linguistic type, there are five patterns among them are five data of Low frequency or word, for example: "Kata yang bikin kita stres yaitu, terserah, sembarang, whatever!" In the utterance, the speaker used another language to ease the viewers to understand the meaning of what the speaker said. He also insert constituents from one language into a structure from the other language. The second pattern covers five data of oversight. It means when the speaker conveys a topic but he has the limitation of the word so the speaker will mix or take the word from other language like "Tapi sekarang kita harus bisa berfikir di luar otak, think outside the box, bok oppoe gendang think outside the box". In the sentence, Indonesian and English are mixed because the words used by the speaker is limitation, so he borrows the word from other language and also constraints on mixing in terms of the compatibility or equivalence of the language involved at the switch point. The third of pattern reveals five data of Pernicious Homonymy means the speaker used a word from another language to solve homonymy problem in his language such as "Per 1000 viewers kalian bakalan dapat uang 1-10 US dollar". In this case, the speaker mixed language to evade ambiguous meaning, so he borrowed the word from another language. It also influenced phonological aspect between both languages when the speaker borrowed the word from another language. The fourth pattern of linguistic type reveals four data of In Sufficiently differentiated. The data found from the factor show meaning of certain have specific intent, for instance habit 
for example from data "Oh, my god! kon ngomong sembarang terserah tak wen es batu arep gon." In the utterance, the speaker mixed languages (English, Indonesian and Javanese) because he often use the word so this case became the habit of the speaker. The last pattern of linguistic type reveals two data of End in Bayu Skak's videos. The data is "Dan jangan lupa buat subscribe, clik.....just clik it, man!" This utterance mixed Indonesian and English which both languages are used to persuade the viewers to click the link and the aim constraints on mixing in terms of the compatibility or equivalence.

Then, the second factor that influences the code mixing is attitudinal type which found three patterns. The researcher found four data of need for synonymy. An example of it is "Wong namanya juga pilihan berarti harus dipilih lah. Get it? Got it? Good!" The speaker mixed some languages (Indonesian, English, and Javanese) because he soften the same meaning or synonymous the aim of the utterance. This case influences the structure of the language used by the speaker which occurs when structure of two languages are alternated indistinctively both at the grammatical and lexical level between structure and from languages. The second of attitudinal type found four data of Social value such as "And you are dead, you are dead, men! Pokko kon, gara-gara kata terserah itu, ya!" The speaker used mixing language because in his communication with other people considered social factors. The use of the word showed the social status of the speaker. Then the last patterns in attitudinal type also found 3 data of Introduction and development of new culture "Cara memutasi bisa lihat sendiri di google, liat dewe males tak jelasno." In the utterance, there are two language mixed because the speaker want to introduce development about social media. Thus, the speaker borrowed the word in another language for other people understand what we told. The speaker also modifies phonological aspect of language in the mixing language.

There are some differences results found by the researcher of the previous studies. The first, a research conducted by Saleh (2017) entitled "An Analysis of CodeMixing Used by Teachers of Zarindah House Learning in the Teaching Learning Process". The result of the research showed 44 data and there were 43 data of code mixing from the 1 st and there were 43 data from the 2 nd teacher. They concluded that there are two types of code mixing used by teachers namely Intra sentential Code Mixing and Involving Change of Pronunciation. The dominant type that the teachers used was Intra sentential code mixing. This research used code mixing because the first 
and the second wanted to give motivation to their students and were expressing her emotion or feeling to the students by using English expression.

The second, done by Hasanah (2017) entitled Code Mixing Analysis in English Vinglish Movie. This study found types of code mixing in English Vinglish Movie that are insertion of word, word reduplication, clause, and phrase. Then, there are six factors that influence of code mixing found in utterances the movie, like as need for synonymy, social value, need for synonymy, introduction and development of new culture, low frequency or word, oversight, and end. In this movie, the character of the name is Sashi mixed his language (Hindi) with English language.

The last research was done by Astuti (2017). The title is "A Study on Code Mixing Found in Perahu Kertas by Dewi Lestari." The result of this research found six levels of code mixing in Perahu Kertas novel. Those are word level, phrase level, clause level, baster level, reduplication level, and idiom level. There are factors of code mixing like as code usage limitation, popular term, speaker and speaker character, conversation partner, domicile and time of conversation, conversation modus, topic, function and aim, types and language speech level, third speaker, main topic, humor and prestigious.

The difference result between this study and those are, in this research, all of types of code mixing used by researcher of the video are insertion, alternation, and congruent lexicalization. This research found in the types of code mixing namely ten data of insertion which lexical item or entire constituents from one language into a structure from the other language. Ten data of alternation occurs when structure of two languages are alternated indistinctively both at the grammatical and lexical level between structure and from languages, and ten data of congruent lexicalization because Indonesian says an English word, but modify it to Indonesian phonological structure.

Based on the analysis, the researcher found there is a thin line that can be seen from this current research and the three previous study. In the first previous study, Teacher 1 and Teacher 2 used code mixing with the aim to use quotation in English, give some motivation to students, and give in order to express emotion or feeling to students by using English expressions.

In second research, the character Sashi used code mixing with the purpose to improve her vocabulary because Sashi has less vocabulary and also does not know the 
meaning of the statement she tells. The third research shows that the character in the novel used code mixing to say terms that are culturally impossible to translate.

In this research, Bayu mixed Javanese, Indonesian, and English language because he always make videos with some title so he told to adapt the topics and his status as a Youtuber which he consider his social factor. Here we can see that people do code mixings with the aim to ease the process of communication. Still, there are other advantages of doing code mixing, such as motivational factor, a social factor, and cultural factor.

\section{CONCLUSION AND SUGGESTIONS}

\section{Conclusion}

There are purposes why Bayu used code mixing are conveying topic so must borrow the word from English mixed with Javanesse and Indonesian, limitation word, social factor, introduce new cultures in entertainment like Youtube, Factor habit, to be easier to remember, and make viewers understand what he told.

Finally, the researcher can conclude that the use of code mixing occurs because of some reasons, such as: to give a motivation to other people, to express emotion of feeling, the limitation of word in both languages, less vocabulary, way to pronounce words and the culture of Indonesian when repeat the English, talking about topic, adaption to surrounding, using idiom in English so became habit, in situation formal and informal.

\section{Suggestion}

The researcher would like to give some suggestions. Certainly, For Bayu Skak, he can introduce Javanese and Indonesian when inform a topics or make video to viewers in the world. The second, the viewers can learn several languages in this video, because know words in foreign language, it can be easier for them to remember word use in daily communication. The last, the result of the research also can be as reference in studying linguistics, especially about sociolinguistics and more specific in code mixing to analyze other videos. 


\section{REFERENCES}

Aiex, N.K. (1999). Mass Media Use in the Classroom. ERIC Digest D147. Bloomington, IN: ERIC Clearinghouse on Reading and Communication Skills.

Adenan, F. (2000). Makna dalam Bahasa (Humaniora 12 2000). Humaniora, XII(3), 261-270. Retrieved from https://jurnal.ugm.ac.id/jurnalhumaniora/article/download/698/544

Fitri, F. A., \& Kurniawan, M. (2017). "A Study on Code Mixing Found in Perahu Kertas Novel by Dewi Lestari” (Doctoral dissertation, IAIN Surakarta).

Cresswell, J. W. (2007). Qualitative Inquiry and Research Design: Choosing among Five Approaches (Third Edit; L. Habib \& M. Masson, eds.). California: SAGE Publications, Inc.

Dictionary.com. (2019). Video. Retrieved June 20, 2019, from https://www.dictionary.com/browse/video?s=t

Hasanah, R. W. (2017). Code Mixing Analysis Used in English Vinglish Movie. Pioneer, 9(1), 24-34. Retrieved from https://jurnal.unars.ac.id/artikel/2018-03-5682-Risqiyatul Hasanah.pdf

$\mathrm{Hu}$, S. (2010). Context of Situation in Translation. Journal of Language Teaching and Research, 1(3), 324-326.

Muysken, P. (2004). Bilingual Speech: A Typology of Code-Mixing (First Edit). Cambridge: Cambridge University Press.

Saleh, S. A. (2017). “An Analysis of Code-Mixing Used by Teachers of Zarindah House of Learning in the Teaching Learning Process" (Doctoral dissertation, Universitas Islam Negeri Alauddin Makassar).

Saville-Troike, M. (2008). The Ethnography of Communication: An Introduction (Vol. 14). John Wiley \& Sons.

Skak, B. (2010). Bayu Skak. Retrieved from https://www.youtube.com/user/bayuekomoektito1

Spradley, J. P. (2016). Participant Observation. Waveland Press.

Wardhaugh, R. (2006). An Introduction to Sociolinguistics (Vol. 28). John Wiley \& Sons. 